\title{
Penerapan Inferensi Backward Chaining Pada Sistem Pakar Diagnosa Awal Penyakit Tulang
}

\author{
Asti Herliana ${ }^{1}$, Visqia Ade Setiawan ${ }^{2}$, Rizki Tri Prasetio ${ }^{3}$ \\ ${ }^{1}$ Universitas BSI \\ email: asti.ala@bsi.ac.id \\ ${ }^{2}$ Universitas BSI \\ email: visqiaadesetiawan@gmail.com \\ ${ }^{3}$ Universitas BSI \\ email: rizki.rte@bsi.ac.id
}

\begin{abstract}
Abstrak
Tulang merupakan bagian yang sangat penting di dalam bagian ortopedi manusia. Tulang bukan hanya kerangka penguat tubuh tetapi juga merupakan bagian dari susunan sendi, sebagai pelindung tubuh, tempat melekatnya bagian ujung otot yang melekat pada tulang. Terbatasnya jumlah pakar Penyakit Tulang serta minimnya pengetahuan masyarakat tentang penyakit tulang menjadi kendala mengapa penyakit ini tidak mudah diatasi. Banyaknya gejala yang mirip untuk menentukan suatu penyakit Tulang. Dari masalah diatas maka dibuatlah aplikasi sistem pakar diagnosa awal penyakit tulang. Dari penelitian yang dilakukan menghasilkan sebuah perangkat lunak Sistem Pendukung Keputusan Klinis berbasis web untuk diagnosa Penyakit Tulang. Informasi yang dihasilkan adalah hasil diagnosa penyakit berdasarkan gejala-gejala yang dipilih oleh user. Hasil uji coba menunjukkan bahwa aplikasi ini layak dan dapat digunakan sebagai alat bantu para medis Penyakit Tulang dalam mendiagnosa awal.
\end{abstract}

Kata Kunci : Sistem Pakar, Penyakit Tulang, Diagnosa awal, Backward Chaining, Web Progaming.

\begin{abstract}
Bone was a very important part in the human orthopedics. Bone is not only the body's reinforcement part, but it is also part of the joints, as a protector of the body, where the attachment of the muscle ends attached to the bone. The limited number of experts in Bone Disease and the lack of public knowledge about bone disease is the reason why this disease is not easy to overcome. The number of similar symptoms for a bone disease. From the above problems then made the application of expert systems early diagnosis of bone disease. From research conducted a software Clinical Decision Support System web-based for the diagnosis of Bone Disease. The resulting information is the result of diagnosis of the disease based on the symptoms chosen by the user. The results of the trial show this application is feasible and can be used as a tool of medical ailments of bone disease in early diagnosis.
\end{abstract}

Keyword : Expert System, Bone Disease, Early Diagnose, Backward Chainning, Web Programming 


\section{Pendahuluan}

Tulang dan kerangka merupakan bagian yang sangat penting di dalam bagian ortopedi. Tulang bukan hanya kerangka penguat tubuh tetapi juga merupakan bagian dari susunan sendi, sebagai pelindung tubuh, tempat melekatnya bagian ujung otot yang melekat pada tulang dengan pergerakan yang tetap atau stabil pada saat kontraksi (origo), bagian ujung otot yang melekat pada tulang dengan pergerakan yang berubah posisi pada saat kontraksi (insertio) dan otot-otot yang menggerakan kerangka tubuh (Helmi, 2013).

Selama ini osteoporosis identik dengan orang tua, namun faktanya pengeroposan tulang bisa menyerang siapa saja termasuk usia muda. Osteoporosis merupakan salah satu penyakit degeneratif. Penelitian terbaru dari International Osteoporosis Foundation (IOF) Mengungkapkan bahwa 1 dari 4 perempuan di Indonesia dengan rentang usia 50-80 tahun memiliki resiko terkena osteoporosis. Resiko osteoporosis perempuan di Indonesia 4 kali lebih tinggi dibandingkan laki-laki. Biasanya penyakit keropos tulang ini menjangkiti sebagian besar wanita paska menopause. Hilangnya hormon esterogen setelah menopause meningkatkan resiko terkena osteoporosis. Mengutip data dari WHO yang menunjukan bahwa di seluruh dunia sekitar 200 juta orang yang menderita osteoporosis atau penyakit tulang lainya (Infodatim, 2015).

Runut balik (Backward chaining) merupakan strategi pencarian yang arahnya kebalikan dari runut mundur (Forward Chaining). Proses pencarian dimulai dari tujuan, yaitu kesimpulan yang menjadi solui permasalahan yang dihadapi. Mesin inferensi mencari kaidah-kaidah dalam basis pengetahuan yang kesimpulannya merupakan solusi yang ingin dicapai, kemudian dari kaidah-kaidah yang di peroleh, masing-masing kesimpulan di runut balik jalur yang mengarah pada kesimpulan tersebut. Metode Backward Chainning dipilih karena sebelumnya telah menunjukan hasil yang cukup baik seperti yang dilakukan oleh Berdasarkan fakta pentingnya penanganan penyakit tulang sejak dini, maka pada penelitian kali ini akan dibahas mengenai sistem pakar diagnosa awal penyakit tulang dengan menggunakan metode inferensi backward chaining, sistem pakar sendiri didefinisikan sebagai suatu sistem komputer yang dapat menyamai kemampuan seorang pakar dalam mengambil keputusan (Arhami, 2005). Dalam penelitian kali ini, sistem pakar diharapkan dapat menstubtitusikan kemampuan yang dimiliki oleh seorang ahli ortopedi (ahli dalam masalah kesehatan, khususnya mengenai penyakit pada tulang)kedalam bentuk program komputer sehingga dapat digunakan oleh banyak orang dan dapat dimanfaatkan untuk menyelesaikan masalah yang dialami secara mandiri tanpa kehadiran seorang pakar secara langsung sehingga dapat disimpulkan diagnosa awalnya.

Begitu pentingnya penelitian mengenai penyakit tulang ini, sehingga para peneliti terdahulu telah membahas solusi untuk diagnose masalah penyakit tulang ini. Adapun beberapa ahli yang dimaksud adalah sebagai berikut :

1. Pada tahun 2012, Winiarti melakukan penelitian yang berjudul Sistem Pendukung Keputusan untuk diagnosa penyakit tulang. Pada penelitian yang dilakukan kali ini disampaikan bahwa kecerdasan buatan (artificial intelligence) merupakan bagian dari ilmu pengetahuan komputer yang ditunjukan pada pembuatan software dan hardware yang seolah-olah sebagai sesuatu yang dapat berpikir seperti manusia. Salah satu kecerdasan buatan yang sedang mengalami perkembangan adalah sistem pakar (expert system) yang diminati karena penerapannya diberbagai bidang baik ilmu pengetahuan maupun bisnis yang terbukti membantu menyelesaikan masalah tertentu dan luas penerapannya.

2. Pada tahun 2012 Dahria melakukan penelitian yang berjudul Implementasi Inferensi Backward Chaining untuk mengetahui kerusakan monitor komputer yang tujuannya untuk memudahkan user melacak kerusakan pada monitor komputer secara mandiri. Kebanyakan sistem pakar berbasis aturan menggunakan strategi inferensi yang dinamakan modus ponen. Berdasarkan strategi ini, jika terdapat aturan "IF A THEN B", dan jika diketahui bahwa A benar, maka dapat disimpulkan bahwa $B$ juga benar. Strategi inferensi modus ponen dinyatakan dalam bentuk [ A AND ( $\mathrm{A} \rightarrow$ 
B )] $\rightarrow$ B dengan A dan A $\rightarrow B$ adalah proposi dalam basis pengetahuan. Pada Penelitian ini menggunakan metode Backward Chaining yaitu upakan strategi pencarian yang arahnya kebalikan dari runut maju (forward chaining).

3. Pada tahun 2011 Wardhani dalam penelitiannya yang berjudul Perancangan Progam Sistem Pakar Untuk Mendiagnosa Penyakit Sendi dan Tulang Pada Manusia, Menfaatkan Teknologi Dongle untuk mengungkapkan bahwa Sistem pakar dibangun berdasarkan basis pengetahuan dan basis aturan. Salah satu penerapan sistem pakar adalah dalam bidang medis, yang dalam penelitian ini ada untuk mendeteksi penyakit sendi dan tulang. Dalam penelitiannya mengungkapkan salah satu tujuan utama dari sistem pakar tersebut adalah dibutuhkan suatu sistem yang bisa melakukan diagnosa terhadap penyakit-penyakit khusus, serta dapat memberikan solusi mengenai pengobatan yang tepat.

4. Pada tahun 2017 Herliana, Yudhiono dan Fitriyani melakukan penelitian sistem pakar untuk diagnosis penyakit Hernia Nukleus Pulposus (HNP) dengan menggunakan metode Forward Chainning. Dari penelitian yang dilakukan, didapatkan sebuah aplikasi berbasis web dalam mendiagnosa gejala awal penyakit HNP. Hasil penelitian yang dilakukan bertujuan agar masyarakat luas dapat mendeteksi sejak dini gejala-gejala dari penyakit ini sehingga dapat dilakukan penanganan lebih dini.

\section{Metode Penelitian Kerangka Berfikir}

Kerangka berfikir dalam metodelogi perancangan ini adalah dimulai dengan identifikasi masalah dan perumusan masalah yang dapat dibuat sistem pakar, kemudian menentukan basis pengetahuan dan jenis inferensi yang akan digunakan sehingga dapat di implementasikan pada aplikasi sistem pakar yang dibuat.

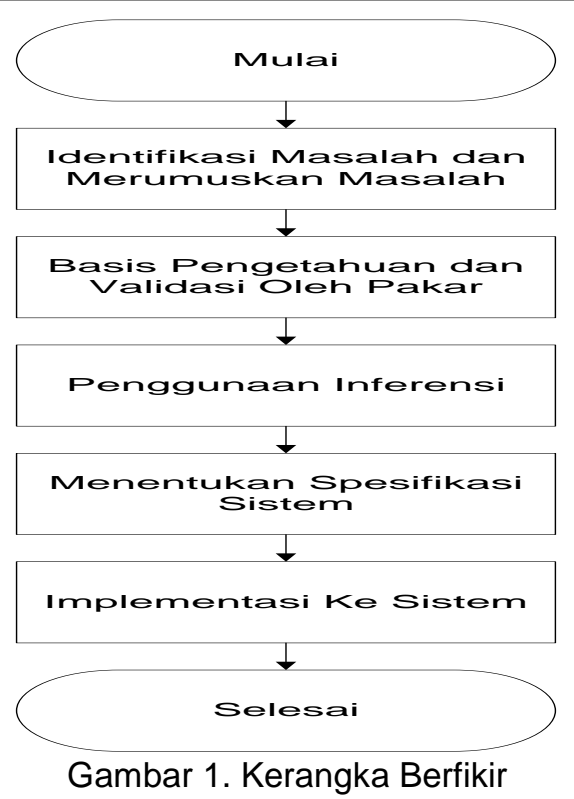

\section{Metode pengumpulan Data}

Pengumpulan data pada penelitian ini dilakukan dengan studi pustaka. Studi pustaka merupakan kegiatan mempelajari kasus dan objek yang diteliti dari sumber tertulis yaitu dapat berupa data dari buku, jurnal, e-book, web site dan lainnya.

\section{Sistem Pakar}

Sistem pakar adalah aplikasi berbasis komputer yang digunakan untuk menyeleasaikan masalah sebagaimana yang dipikirkan oleh pakar. Pakar yang dimaksud disini adalah orang yang mempunyai keahlian khusus yang dapat menyeleasaikan masalah yang tidak dapat diselesaikan oleh orang awam. Sebagai contoh, dokter adalah seirang pakar yang mampu mendiagnosis penyakit yang diderita oleh pasien serta dapat memberikan penatalaksanaan terhadap penyakit tersebut (Kusrini, 2008).

\section{Inferensi Backward Chaining}

Runut balik (Backward chaining) merupakan strategi pencarian yang arahnya kebalikan dari runut mundur (Forward Chaining). Proses pencarian dimulai dari tujuan, yaitu kesimpulan yang menjadi solui permasalahan yang dihadapi. Mesin inferensi mencari kaidah-kaidah dalam basis pengetahuan yang kesimpulannya merupakan solusi yang ingin dicapai, kemudian dari kaidah-kaidah yang di peroleh, masing-masing kesimpulan di runut balik jalur yang mengarah pada kesimpulan tersebut. 


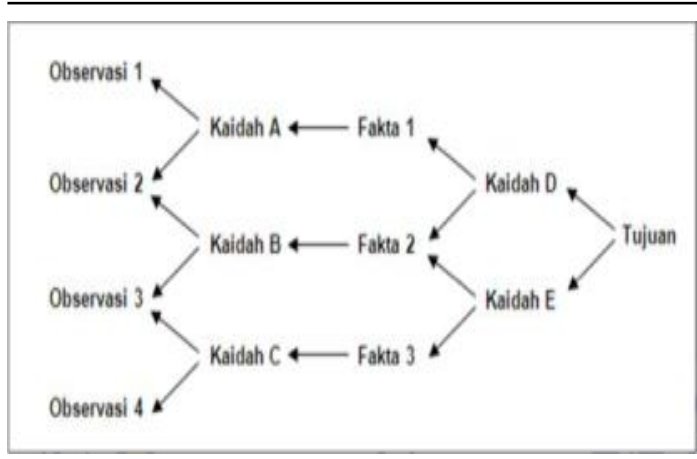

Gambar 2. Inferensi Backward Chaining Sumber : (Dahria, 2012)

Tabel Basis Pengetahuan

\begin{tabular}{|c|l|}
\multicolumn{2}{c}{ Tabel 1. Tabel Penyakit } \\
\begin{tabular}{|c|l|}
\hline \multicolumn{2}{|c|}{ DAFTAR PENYAKIT } \\
\hline Kode & \multicolumn{1}{|c|}{ Nama Penyakit } \\
\hline P01 & Osteoarthritis \\
\hline P02 & Deman Reumatik \\
\hline P03 & Artritis Reumatik \\
\hline P04 & Osteoporosis \\
\hline P05 & Paget Tulang \\
\hline P06 & Legg Calve Perthes \\
\hline P07 & Dysplasia Fibrosa \\
\hline P08 & Osteomyelitis \\
\hline
\end{tabular}
\end{tabular}

Tabel 2. Tabel Gejala

\begin{tabular}{|l|l|}
\hline \multicolumn{2}{|c|}{ DAFTAR GEJALA } \\
\hline Kode & \multicolumn{1}{|c|}{ Nama Gejala } \\
\hline G01 & $\begin{array}{l}\text { Nyeri dalam yang terlokasi di daerah } \\
\text { sendi atau tulang yang terkena }\end{array}$ \\
\hline G02 & Nyeri pada malam hari \\
\hline G03 & Kekakuan sendi pada pagi hari \\
\hline G04 & Mudah letih dan lemas \\
\hline G05 & Kelenturan sendi yang menurun \\
\hline G06 & Demam \\
\hline G07 & $\begin{array}{l}\text { Muncul bentolan di bawah kulit pada } \\
\text { daerah bertulang }\end{array}$ \\
\hline G08 & Peradangan sendi disertai rasa sakit \\
\hline G09 & Terasa panas pada daerah bertulang \\
\hline G10 & Nyeri sendi \\
\hline G11 & Kekakuan membaik dengan gerakan \\
\hline G12 & Gejala cenderung hilang dan timbul \\
\hline G13 & Baal atau kesemutan \\
\hline G14 & $\begin{array}{l}\text { Muncul nyeri punggung bawah dan } \\
\text { nyeri leher }\end{array}$ \\
\hline G15 & Postur bungkuk \\
\hline G16 & Penurunan tinggi badan secara bertahap \\
\hline G17 & Gangguan makan \\
\hline G18 & Sakit tulang bagian tertentu \\
\hline G19 & Nyeri sendi disertai kaku \\
\hline G20 & Kelainan bentuk tulang \\
\hline G21 & Kesemutan dan lesu \\
\hline
\end{tabular}

\begin{tabular}{|l|l|}
\hline G22 & Sakit leher dan kepala \\
\hline G23 & Kehilangan pendengaran \\
\hline G24 & $\begin{array}{l}\text { Kulit tangan bengkak disekitar tulang } \\
\text { yang terpengaruh }\end{array}$ \\
\hline G25 & Berawal dari sakit pinggul \\
\hline G26 & Nyeri pada paha \\
\hline G27 & Nyeri pada lutut atau selangkangan \\
\hline G28 & $\begin{array}{l}\text { Nyeri akan sembuh tanpa cidera apapun } \\
\text { di area sakit }\end{array}$ \\
\hline G29 & $\begin{array}{l}\text { Pincang dan sulit berjalan karena rasa } \\
\text { nyeri }\end{array}$ \\
\hline G30 & Fraktur \\
\hline G31 & Jeratan saraf \\
\hline G32 & Bitnik-bintik coklat muda pada kulit \\
\hline G33 & $\begin{array}{l}\text { Bertambah buruk ketika melakukan } \\
\text { aktivitas yang berat }\end{array}$ \\
\hline G34 & Demam tinggi \\
\hline G35 & $\begin{array}{l}\text { Daerah sekitar tulang dan sendi } \\
\text { mengalami bengkak merah }\end{array}$ \\
\hline G36 & Menggigil \\
\hline G37 & Merasa tidak nyaman dan khawatir \\
\hline G38 & Mual dan berkeringat \\
\hline
\end{tabular}

Tabel 3. Tabel keputusan pakar

\begin{tabular}{|c|c|c|c|c|c|c|c|c|}
\hline $\begin{array}{c}\text { Kod } \\
\mathrm{e}\end{array}$ & $\begin{array}{l}P \\
1\end{array}$ & $P$ & $\begin{array}{l}P \\
3\end{array}$ & $\begin{array}{l}P \\
4\end{array}$ & $\begin{array}{l}P \\
5\end{array}$ & $\begin{array}{l}P \\
6\end{array}$ & $\begin{array}{l}P \\
7\end{array}$ & $\begin{array}{l}P \\
8\end{array}$ \\
\hline G01 & $\bar{X}$ & & & & & & & \\
\hline G02 & $X$ & & & & & & & \\
\hline G03 & $\bar{X}$ & & & & & & & \\
\hline G04 & $\bar{X}$ & & & & & & & \\
\hline G05 & $X$ & & & & & & & \\
\hline G06 & & $X$ & & & & & & \\
\hline G07 & & $X$ & & & & & & \\
\hline G08 & & $X$ & & & & & & \\
\hline G09 & & $\mathrm{X}$ & & & & & & \\
\hline G10 & & & $X$ & & & & & \\
\hline G11 & & & $X$ & & & & & \\
\hline G12 & & & $\bar{X}$ & & & & & \\
\hline G13 & & & $X$ & & & & & \\
\hline G14 & & & & $X$ & & & & \\
\hline G15 & & & & $X$ & & & & \\
\hline G16 & & & & $X$ & $X$ & & & \\
\hline G17 & & & & $X$ & & & & \\
\hline G18 & & & & & $X$ & & & $X$ \\
\hline G19 & & & & & $X$ & & & \\
\hline G20 & & & & & $X$ & & & \\
\hline G21 & & & & & $X$ & & & \\
\hline G22 & & & & & $\mathrm{X}$ & & & \\
\hline G23 & & & & & $X$ & & & \\
\hline G24 & & & & & $X$ & & & \\
\hline G25 & & & & & & $X$ & & \\
\hline G26 & & & & & & $X$ & & \\
\hline G27 & & & & & & $X$ & & \\
\hline G28 & & & & & & $X$ & & \\
\hline G29 & & & & & & $X$ & $X$ & \\
\hline
\end{tabular}




\begin{tabular}{|l|l|l|l|l|l|l|l|l|}
\hline G30 & & & & & & & X & \\
\hline G31 & & & & & & & X & \\
\hline G32 & & & & & & & X & \\
\hline G33 & & & & & & & X & \\
\hline G34 & & & & & & & & X \\
\hline G35 & & & & & & & & X \\
\hline G36 & & & & & & & & X \\
\hline
\end{tabular}

And mudah letih dan lemas

And kelenturan sendi yang menurun

Then osteoartritis

\section{Rule Kedua}

If Demam

And munculnya bentolan di bawah kulit pada daerah bertulang

And Peradangan sendi diserti rasa sakit

\section{Logika Sistem Pakar}

Berikut uraian rule-rule dari sistem pakar diagnosa awal penyakit tulang menggunakan metode inferensi Backward Chaining.

\section{Rule Pertama}

If nyeri dalam yang terlokasi pada sendi yang terdena

And nyeri pada malam hari

And terasa panas pada daerah yang bertulang

Then Demam Reumatik

\section{Rule Ketiga}

If nyeri sendi

And kekakuan membaik dengan gerakan

And gejala cenderung hilang dan timbul

And baal atau kesemutan

Then Artritis Reumatik

\section{Pohon Pakar}

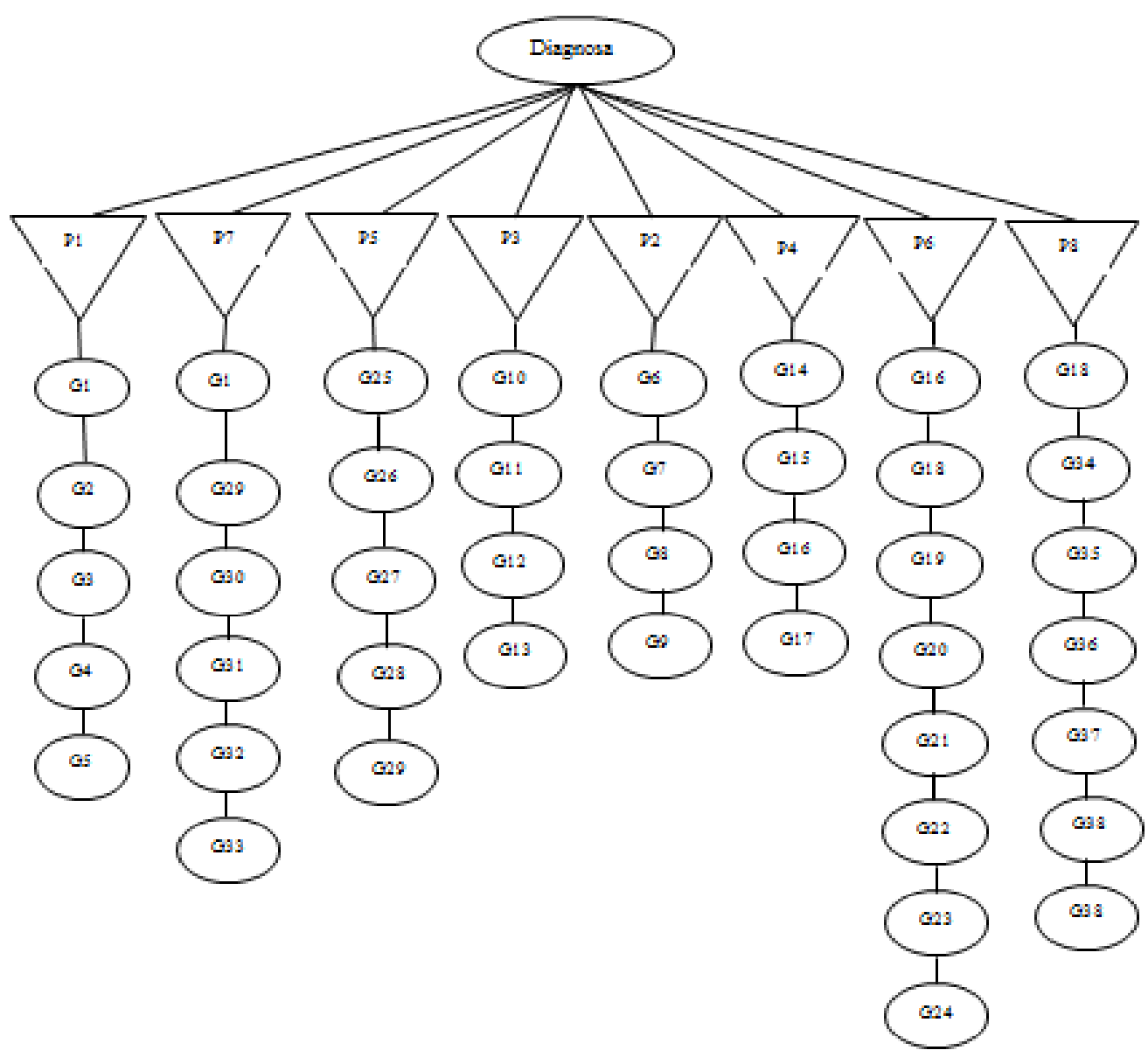

Gambar 3. Pohon Pakar 


\section{Hasil dan Pembahasan}

Berdasarkan hasil dari kajian penelitian yang telah dilakukan, maka hasil dan pembahasan yang didapat pada penelitian kali ini dijabarkan sebagai berikut :
3.1. Entity Relationship Diagram

Entity Relationship Diagram menggambarkan rancangan basis data yang digunakan dalam sistem pakar ini.

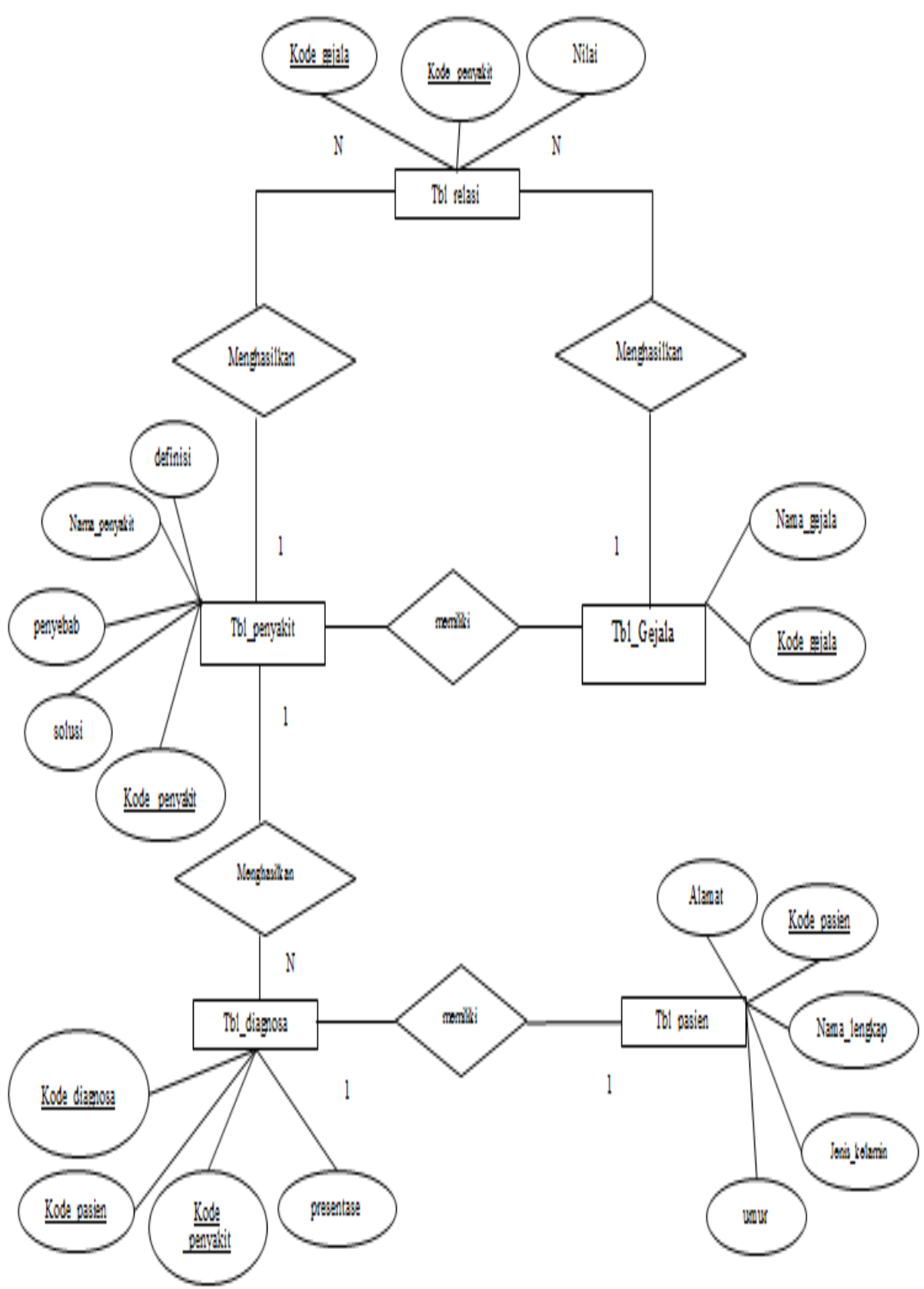

Gambar 4. Entity Relationship Diagram 
3.2. UML (Unified Modeling Language) Pada Diagram UML yang meliputi usecase diagram dan activity diagram yang menggambarkan apa saja yang dapat di lakakukan oleh user

1. Use Case Diagram

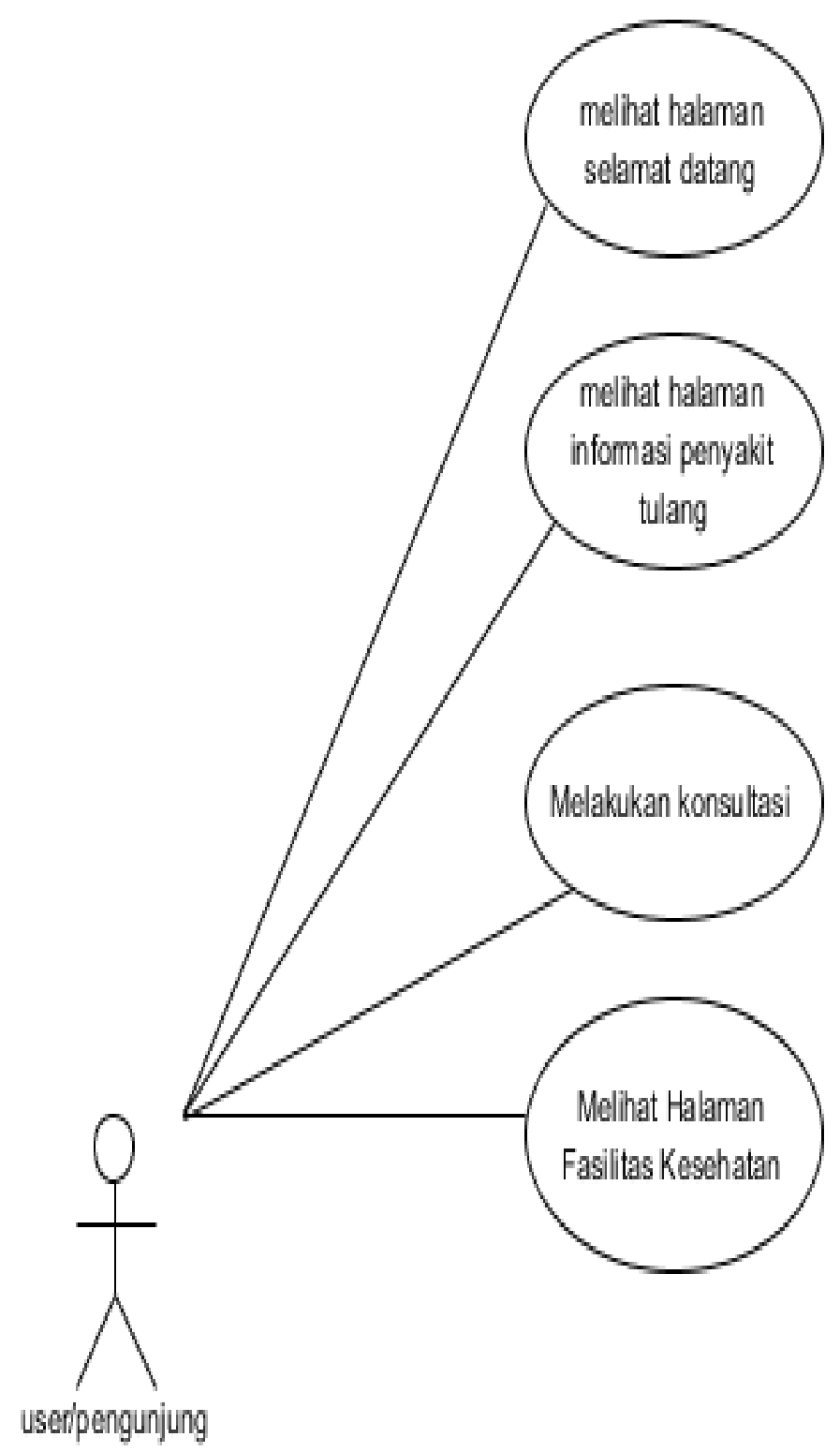

Gambar 5. Use Case Diagram User 


\section{Activity Diagram}

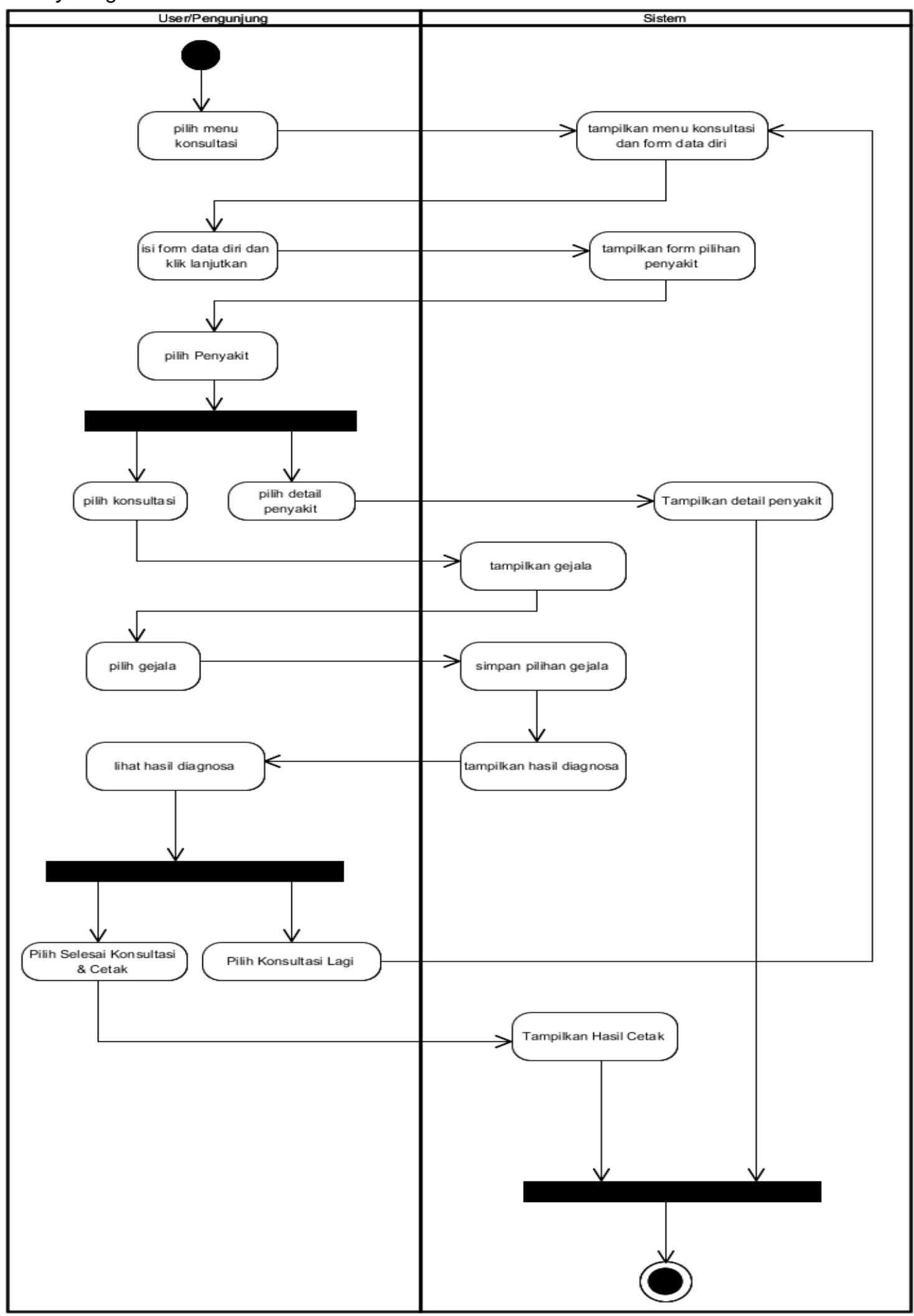

Gambar 6. Activity Diagram Konsultasi 


\subsection{Implementasi Sistem}

A. Halaman Admin

Halaman admin merupakan halaman yang dapat digunakan hanya oleh admin sistem yang sudah terdaftar dan dapan mengakses penuh untuk memodifikasi data yang ada.

1. Form Login

Form login digunakan oleh admin untuk masuk ke halaman admin. Login admin dapat dilakukan dengan mengisi username dan password yang sesuai dan sudah terdaftar pada tabel admin sebelumnya.

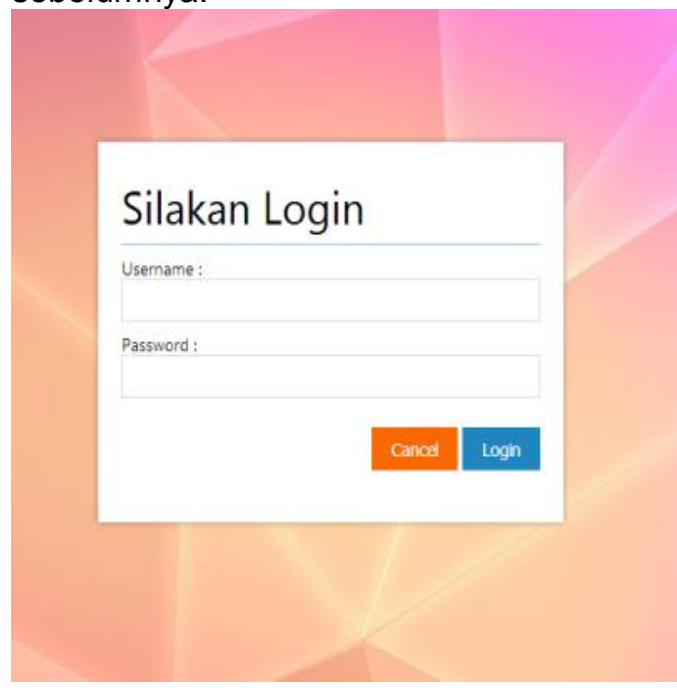

Gambar 7. Form Login Admin

2. Halaman Beranda

Halaman beranda untuk admin menandakan bahwa login adin telah berhasil.

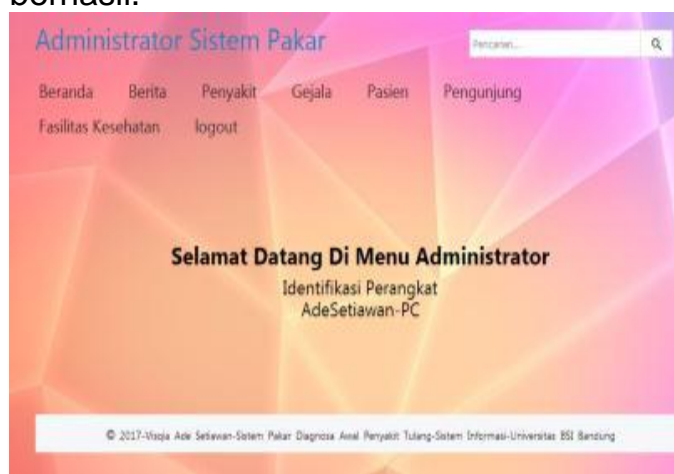

Gambar 8. Halaman Beranda Admin

3. Halaman kelola penyakit

Halaman kelola penyakit berisi daftar penyakit dan dapat memodifikasi data antara lain tambah, edit dan hapus data.

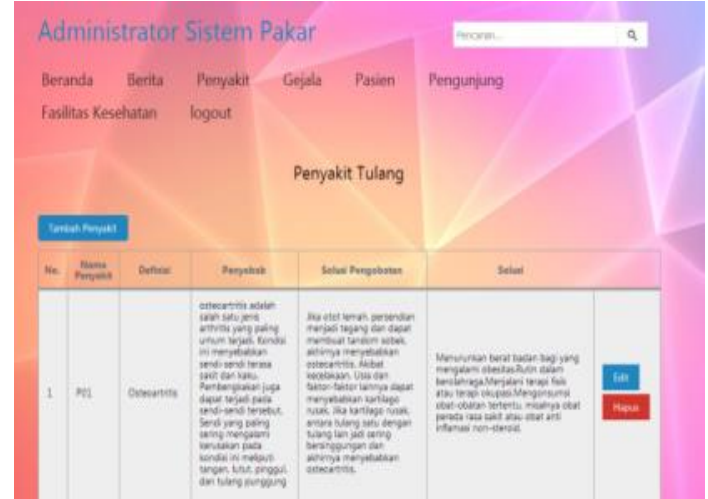

Gambar 9. Halaman kolola penyakit

4. Halaman kelola gejala

Halaman kelola gejala berisi daftar penyakit dan dapat memodifikasi data antara lain tambah, edit dan hapus data

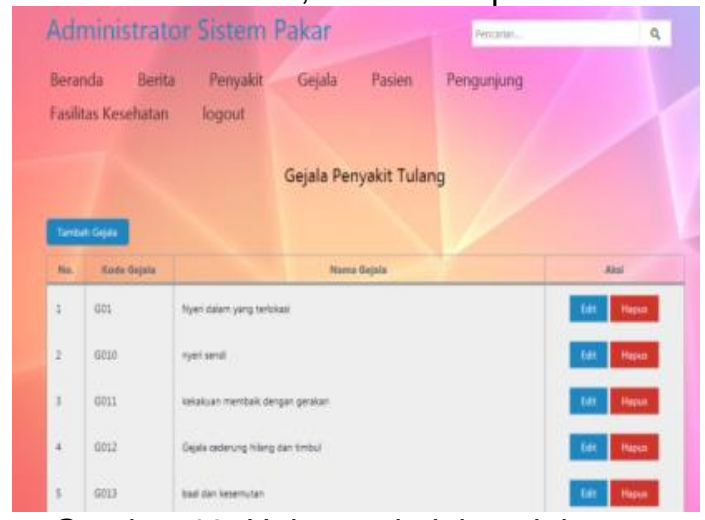

Gambar 10. Halaman kelola gejala

5. Halaman kelol pasien

Halaman kelola pasien berisi daftar pasien beserta hasil diagnosanya

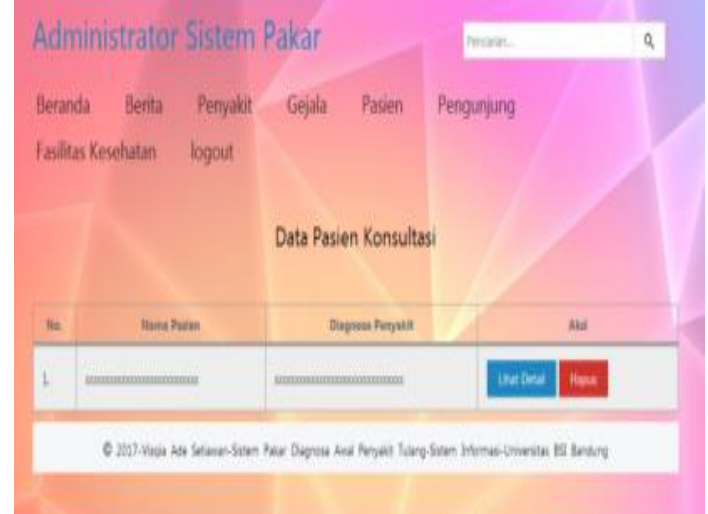

Gambar 11. Halaman kelola pasien 
6. Halaman fasilitas kesehatan Halaman fasilitas kesehatan berisi daftar fasilitas kesehatan dan dapat memodifikasi data antara lain tambah, edit dan hapus data.

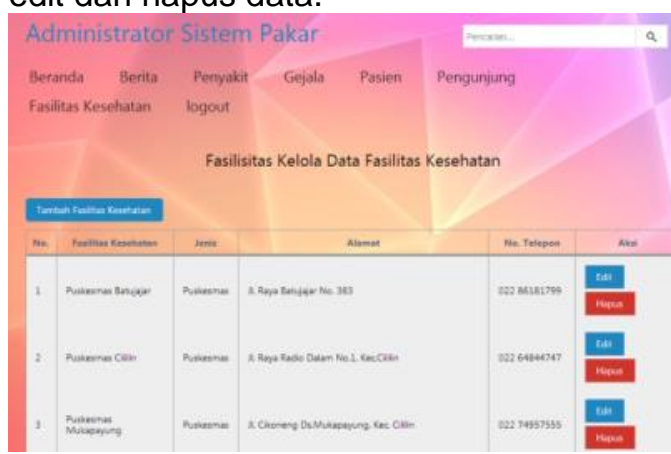

Gambar 12. Halaman fasilitas kesehatan

B. Halaman User

1. Halaman selamat datang

Halaman selamat datang adalah haalaman awal untuk mendata pengunjung pada apliksi sistem pakar.

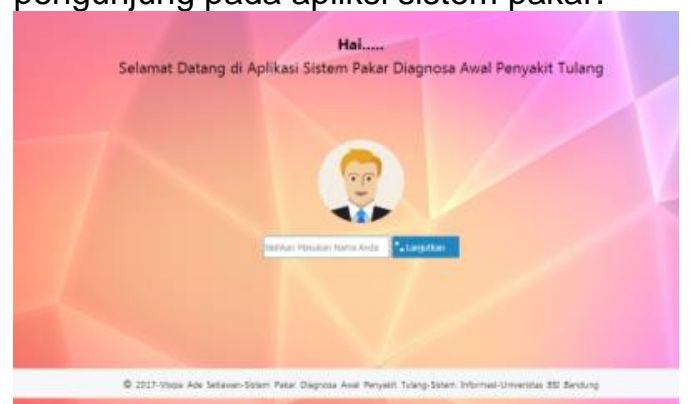

Gambar 13. Halaman selamat datang

2. Halaman informasi penyakit Halaman yang berisi tentang informsi penyakit tulang

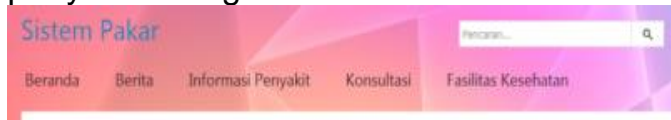

Silahkan Pilih Jenis Penyakit Yang Ingin Anda Cari Tahu
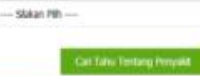

Detail Penyakit yang Anda Pilih

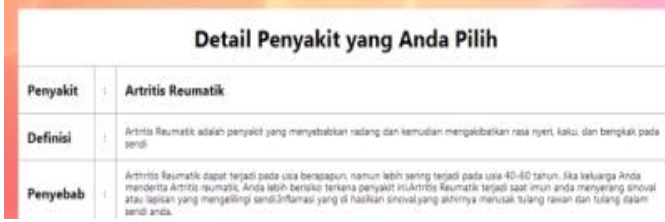

Gambar 14. Halaman informasi penyakit
3. Halaman konsultasi

Halaman tentang konsultasi penyakit berdasarkan penyakit yang dipilih dan gejala yang mungkin muncul

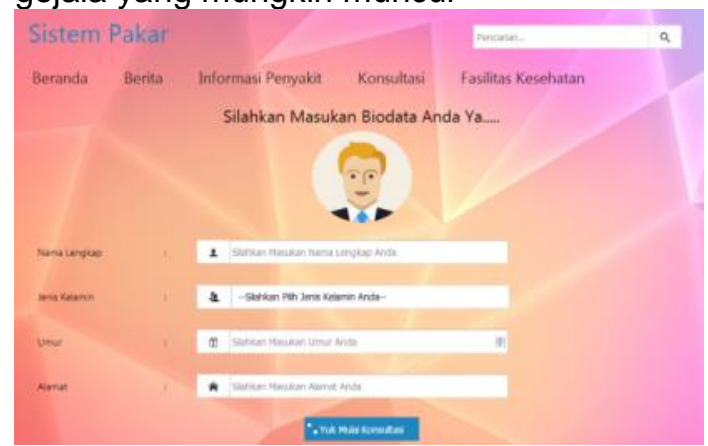

Gambar 15. konsultasi 1

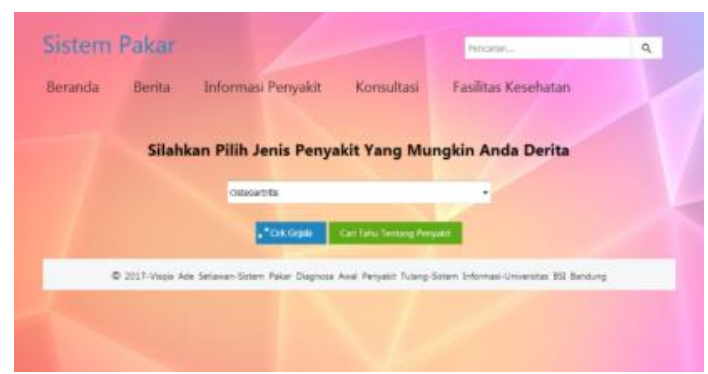

Gambar 16. konsultasi 2

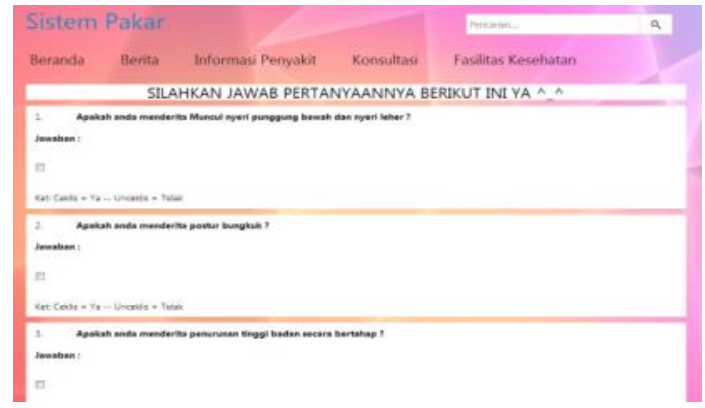

Gambar 17. konsultasi 3

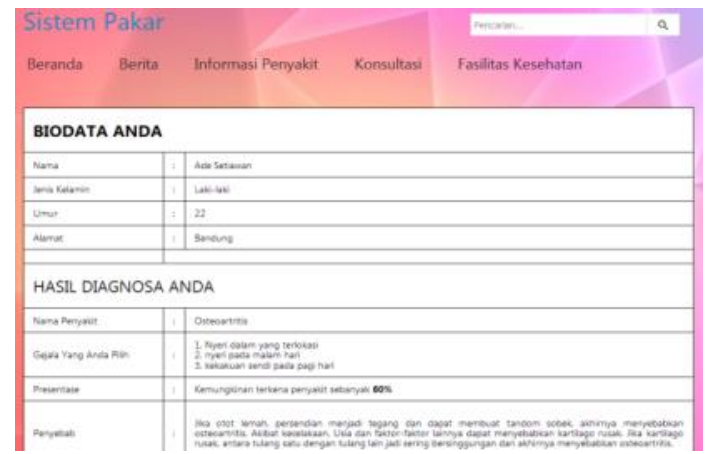

Gambar 18. konsultasi 4 


\section{Kesimpulan}

Pada sistem pakar diagnosa awal penyakit tulang ini terdapat 8 jenis penyakit yang memiliki total 39 gejala. Solusi diberikan sebagai langkah awal dalam menangani penyakit secara dini dan bisa dilakukan dirumah. Sehingga dapat digunakan untuk membantu masyarakat untuk mengenali atau mendiagnosa awal penyakit tulang secara dini.

Sistem pakar diagnosa awal penyakit tulang ini menggunakan metode inferensi backward chaining. Dengan alur user/pengunjung mengisi biodata lalu user/pengunjung memilih penyakit dan menjawab pertanyaan yang sesuai dengan penyakit yang dipilih sehingga didapatkan hasil presentase dan sulusi dari diagnosa penyakit tulang yan diperoleh.

Data yang ada pada aplikasi ini telah di validasi oleh 3 pakar (dokter) yang telah ahli dan berpengalaman di bidangnya kurang lebih selama 10 tahun. Sehingga hasil yang di dapat dipertanggung jawabkan adanya. Diharapkan aplikasi ini selain membantu mendiagnosa penyakit tulang, juga di harapkan dapat dapat memberika informasi dan edukasi kepada masyarakat luas secara umum.

\section{Referensi}

Arhami, M. (2005). Konsep Dasar Sistem Pakar. Yogyakarta: Andi.

Dahria, M. (2012). Jurnal SAINTIKOM Vol.11 / No.1 / Januari 2012. Implementasi Inferensi Backward Chaining Untuk Mengetahui Kerusakan Monitor Komputer, 1-9.

Helmi, Z. N. (2013). Buku Ajar Gangguan Muskuloskeletal. Jakarta: Salemba Medika.

Herliana, A., Yudhiono, N. F., \& Fitriyani. (2017). Sistem Pakar Diagnosis Penyakit Hernia Nukleus Pulposus Menggunakan Forward Chainning Berbasis Web. Jurna Kajian IImiah Vol.17, No.3, September 2017, 8695.

Infodatim. (2015). Data Dan Penyakit Osteoporosis Di Indonesia. Jakarta: Pusat Data Dan Informasi Kementrian Kesehatan Indonesia.
Kusrini. (2008). Sistem Pakar Teori dan Aplikasi. Yogyakarta: Andi.

Wardhani, J. R. (2011). Jurnal Teknologi Informasi-Aiti, Vol. 8. No.2, Agustus 2011 : 101 - 200. Perancangan Progam Sistem Pakar Untuk Mendiagnosa Penyakit Sendi Dan Tulang Pada Manusia Dengan Menfaatkan Teknologi Dongle, 1-16.

Winiarti, S. (2012). ISSN : 1963-6590. Sistem Pendukung Keputusan Klinis Untuk Diagnosa Penyakit Tulang, 110. 